\title{
Induction of endothelial cell apoptosis by the antivascular agent 5,6-dimethylxanthenone-4-acetic acid
}

\section{L-M Ching*,', Z Cao', C Kieda'2, S Zwain', MB Jameson' and BC Baguley'}

'Auckland Cancer Society Research Centre, University of Auckland School of Medicine, Private Bag 92019, Auckland, New Zealand; ${ }^{2}$ Centre de Biophysique Moleculaire, CNRS UPR430I, Orléans, France

5,6-Dimethylxanthenone-4-acetic acid, synthesised in this laboratory, reduces tumour blood flow, both in mice and in patients on Phase I trial. We used TUNEL (TdT-mediated dUTP nick end labelling) assays to investigate whether apoptosis induction was involved in its antivascular effect. 5,6-Dimethylxanthenone-4-acetic acid induced dose-dependent apoptosis in vitro in HECPP murine endothelial cells in the absence of up-regulation of mRNA for tumour necrosis factor. Selective apoptosis of endothelial cells was detected in vivo in sections of Colon 38 tumours in mice within 30 min of administration of 5,6Dimethylxanthenone-4-acetic acid $\left(25 \mathrm{mg} \mathrm{kg}^{-1}\right)$. TUNEL staining intensified with time and after $3 \mathrm{~h}$, necrosis of adjacent tumour tissue was observed. Apoptosis of central vessels in splenic white pulp was also detected in tumour-bearing mice but not in mice without tumours. Apoptosis was not observed in liver tissue. No apoptosis was observed with the inactive analogue 8-methylxanthenone-4-acetic acid. Positive TUNEL staining of tumour vascular endothelium was evident in one patient in a Phase I clinical trial, from a breast tumour biopsy taken 3 and $24 \mathrm{~h}$ after infusion of 5,6-Dimethylxanthenone-4acetic acid $\left(3.1 \mathrm{mg} \mathrm{m}^{-2}\right.$ ). Tumour necrosis and the production of tumour tumour necrosis factor were not observed. No apoptotic staining was seen in tumour biopsies taken from two other patients (doses of 3.7 and $4.9 \mathrm{mg} \mathrm{m}^{-2}$ ). We conclude that 5,6-Dimethylxanthenone-4-acetic acid can induce vascular endothelial cell apoptosis in some murine and human tumours. The action is rapid and appears to be independent of tumour necrosis factor induction. British Journal of Cancer (2002) 86, 1937 - 1942. doi: I0.I 038/sj.bjc.6600368 www.bjcancer.com

(c) 2002 Cancer Research UK

Keywords: DMXAA; apoptosis; antivascular; Colon 38 tumour; endothelial

DMXAA (5,6-dimethylxanthenone-4-acetic acid), a new anticancer agent synthesised in this laboratory (Rewcastle et al, 1991), has recently completed Phase I clinical trial as an antivascular agent. In preclinical studies, DMXAA was particularly effective against transplantable murine tumours with an established vasculature (Rewcastle et al, 1991), where it caused cessation of tumour blood flow, vascular collapse and tumour necrosis (Zwi et al, 1994a; Lash et al, 1998). DMXAA increased tumour necrosis factor (TNF) concentrations in plasma of both tumour bearing and non-tumour bearing mice (Philpott et al, 1995). It induced TNF synthesis in both host and tumour cells of Colon 38 tumours (Joseph et al, 1999) and also induced significant amounts of TNF in murine Colon 38 tumours implanted in TNF knockout mice (Ching et al, 1999). DMXAA also induced TNF synthesis in host cells, and in some cases tumour cells, of a series of human tumour xenografts (Joseph et al, 1999). Co-administration of anti-TNF antibody together with DMXAA partially reversed the blood flow inhibition and antitumour action of DMXAA, suggesting that TNF plays a role in its antivascular effects (Browne et al, 1998).

In contrast to the large increases in plasma TNF observed in mice treated with DMXAA, plasma TNF levels in patients treated in a Cancer Research UK phase I trial were not elevated (Jameson et al, 2000). However, dynamic contrast-enhanced magnetic reso-

*Correspondence: L-M Ching; E-mail: I.ching@auckland.ac.nz Received 12 December 200I; revised II April 2002; accepted 16 April 2002 nance imaging suggested that tumour blood flow was inhibited in most patients receiving DMXAA at doses of $500 \mathrm{mg} \mathrm{m}^{-2}$ or higher (Rustin et al, 1998). These studies suggested that at least some of the antivascular effects of DMXAA might be independent of plasma TNF production and result from a direct effect on tumour vasculature. In this report, we have searched for direct evidence of such an effect, using both in vitro and in vivo murine models and tumour biopsies from three patients treated with DMXAA in a Phase I trial.

\section{MATERIALS AND METHODS}

\section{Materials}

DMXAA was synthesised in this laboratory (Rewcastle et al, 1991) and dissolved in $5 \%$ sodium bicarbonate for intraperitoneal injection into mice $\left(25 \mathrm{mg} \mathrm{kg}^{-1}\right)$ in a volume of $0.01 \mathrm{ml} \mathrm{g}^{-1}$ body weight. DMXAA was dissolved directly in culture medium for in vitro experiments. In the clinical phase trial conducted in Auckland, New Zealand, DMXAA was administered as a $20 \mathrm{~min}$ intravenous infusion on a 3-weekly schedule, using a pre-formulated solution of $20 \mathrm{mg} \mathrm{ml}^{-1}$ in $0.1 \mathrm{M}$ phosphate buffer at pH 7.7 (Jameson et al, 2000).

\section{Mouse studies}

Athymic or normal C57Bl/6 mice were from the Animal Laboratories, University of Auckland School of Medicine. All mice were 
maintained under constant temperature and humidity according to institutional ethical guidelines and used between $8-12$ weeks of age. All animal experiments have been carried out with ethical committee approval. The ethical guidelines that were followed meet the standards required by the UKCCCR guidelines (Workman et al, 1998). Colon 38 tumour fragments $\left(1 \mathrm{~mm}^{3}\right)$ were implanted subcutaneously in the left flank of anaesthetised (sodium pentobarbitone, $86 \mathrm{mg} \mathrm{kg}^{-1}$ ) normal $\mathrm{C} 57 \mathrm{Bl} / 6$ mice. Tumours were used when they had reached approximately $6 \mathrm{~mm}$ in diameter, generally 9-10 days after implantation. Three mice were used for each time point and treatment, and 2-4 cryosections per organ per mouse were immunostained for apoptosis using TUNEL.

\section{Clinical studies}

Three patients with superficial tumours (two with chest wall recurrence of breast adenocarcinoma and one with subcutaneous ovarian adenocarcinoma tumour nodules) consented to biopsies. These samples were taken prior to infusion of DMXAA then at various intervals afterwards and were embedded (OCT compound, a mixture of water-soluble glycols and resins, Tissue-Tek ${ }^{\circledR}$, Sakura Finetech, Torrance, CA, USA) and snapfrozen. Representative cryosections were immunostained for apoptosis using TUNEL.

\section{In vitro studies}

The HECPP murine endothelial cell line derived from endothelial cells isolated from murine Peyer's patches (Bizouarne et al, 1993) was maintained in M199 media (Gibco BRL) with antibiotics and $10 \%$ foetal calf serum at $37^{\circ} \mathrm{C}$ under humidified atmosphere of $5 \% \mathrm{CO}_{2}$. Sub-confluent cultures (that had been passaged the previous day) were incubated with DMXAA for the appropriate time. The supernatant containing non-adherent cells was removed and centrifuged at $300 \times \mathbf{g}$ for $10 \mathrm{~min}$. Adherent cells were lifted from the dishes by trypsinisation and collected similarly. Combined adherent and supernatant cells, resuspended in culture medium $(0.4 \mathrm{ml})$, were used to prepared cytospin preparations that were assayed for apoptosis.

\section{Apoptosis assay}

Apoptosis was determined using the TUNEL assay for identification of double-stranded DNA breaks using an In Situ Cell Death Detection Kit (Boehringer Mannheim) according to manufacturer's instructions. Tissue and tumour cryosections or cytospots of cells on poly-L-lysine-treated slides were fixed in $4 \%$ paraformaldehyde for $30 \mathrm{~min}$ at room temperature, washed with PBS (phosphate buffered saline) and then treated with permeabilisation solution $(0.1 \%$ Triton $\mathrm{X}-100$ in $0.1 \%$ sodium citrate) for $2 \mathrm{~min}$ on ice. Strand breaks were labelled with fluoresceinated dUTP and visualised following reaction with phosphatase-conjugated antibody to fluorescein and Vector ${ }^{\mathbb{R}}$ Black alkaline phosphatase substrate solution (Vector Laboratories, Burlingame, CA, USA). All slides were counter stained using methyl green.

Cryosections of Colon 38 tumour tissues were also stained for endothelial cells to differentiate between apoptosis of the endothelium and apoptosis of tumour cells. Sections were first processed for apoptosis as described and then immunostained for endothelial cells using a rat anti-mouse CD-31 antibody (MEC 13.3, a generous gift from Dr A Vecchi, Instituto di Rierche Farmacologie Mario Negri, Via Eritrea, Milan, Italy) (Vecchi et al, 1994), followed by incubation with biotinylated anti-rat IgG secondary antibody (Vector Laboratories, Burlingame, CA, USA) and the avidin-biotin complex (Vectastain ${ }^{\mathrm{B}}$ ABC-AP Kit). Immunoglobulin complexes were visualised using Vector ${ }^{\circledR}$ Red alkaline phosphatase substrate solution.

\section{Northern blot analysis}

Total cellular RNA was extracted using RNAzol (Gibco, BRL) according to manufacturer's instructions. RNA $(10 \mu \mathrm{g})$ was denatured and electrophoresed in 1\% agarose-formaldehyde gels as previously described (Ching et al, 1994). RNA was then transferred by capillary action onto nylon membrane (Hybond- ${ }^{+}$, Amersham). The membranes were UV-crosslinked (120 mJoule, UVStratalinker, Stratagene, San Diego, CA, USA $)$ and baked $\left(80^{\circ} \mathrm{C}\right.$ for $30 \mathrm{~min})$. Each membrane was prehybridised $\left(2 \mathrm{~h}, 42^{\circ} \mathrm{C}\right)$ in $7 \mathrm{ml}$ hybridisation mix containing $50 \%$ formamide, $0.075 \mathrm{M}$ sodium chloride, $0.05 \mathrm{M}$ sodium dihydrogen phosphate, $5 \mathrm{~mm}$ EDTA, $0.001 \%$ polyvinyl pyrrolidone, $0.001 \%$ bovine serum albumin, $0.001 \%$ Ficoll, $0.01 \mathrm{mg} \mathrm{ml}^{-1}$ herring sperm DNA, and $0.5 \%$ SDS (sodium dodecyl sulphate). The cDNA to the cytokine gene of interest was labelled with $\alpha^{32} \mathrm{P}$-dCTP (Amersham) using a random priming kit (RTS Radprime DNA labelling system, Gibco BRL). Excess radioactivity was removed by elution through a G-50 Sephadex column and labelled probe $\left(10^{6}\right.$ c.p.m. $\mathrm{ml}^{-1}$ hybridisation mix) was then added to the membrane and hybridised for $36 \mathrm{~h}$ at $42^{\circ} \mathrm{C}$. The blots were washed twice in $2 \times$ SSC (standard saline citrate) with $0.1 \%$ SDS for $10 \mathrm{~min}$ at $42^{\circ} \mathrm{C}$, and finally in $0.2 \times$ SSC with $0.1 \%$ SDS for $10 \mathrm{~min}$ at $65^{\circ} \mathrm{C}$. Blots were exposed to X-ray film for $1-3$ days at $-70^{\circ} \mathrm{C}$. After hybridisation with one probe, membranes were stripped (two washes in $300 \mathrm{ml}$ $0.1 \times$ SSC with $1 \%$ SDS for $15 \mathrm{~min}$ at $80^{\circ} \mathrm{C}$ ) and re-hybridised with another probe. The signal intensity was quantitated by laser densitometric scanning. Loading of lanes was determined from the intensity of bands hybridised with the probe for glyceraldehyde3-phosphate dehydrogenase (GADPH).

\section{RESULTS}

\section{Induction of endothelial cell apoptosis in murine tissues following DMXAA}

Sections of Colon 38 tumours, removed at different times from C57Bl/6 mice administered DMXAA at its maximum tolerated dose $\left(25 \mathrm{mg} \mathrm{kg}^{-1}\right)$, were double stained for apoptosis and for CD31 expression (Table 1). As early as $30 \mathrm{~min}$ after treatment, faint apoptotic staining above background staining of untreated controls (Figure 1A) was detected and found to be associated with the endothelial cells in the Colon 38 tumour (Figure 1B). The staining intensity, as well as the number of apoptotic vessels, increased progressively with time after treatment (Table 1). Up to $3 \mathrm{~h}$ after treatment, apoptosis was associated only with the tumour vascular endothelium, with no apoptosis of tumour cells (Figure 1B,C). Colon 38 sections taken $3 \mathrm{~h}$ after DMXAA administration contained intensely stained apoptotic vessels, and at this time, large areas of necrosis of the tumour were observed (Figure 1D). Following the maximal tolerated dose of DMXAA, $69 \%$ of the vessels in the tumour were apoptotic, while after a dose of $15 \mathrm{mg} \mathrm{kg}^{-1}, 27 \%$ were apoptotic. Significant apoptosis of vessels was not observed following DMXAA doses of 5 or $10 \mathrm{mg} \mathrm{kg}^{-1}$ (Table 1). Colon 38 tumour sections removed from mice $3 \mathrm{~h}$ after treatment with an inactive analogue, 8-MeXAA (8-methylxanthenone-4-acetic acid) at its maximal tolerated dose $\left(220 \mathrm{mg} \mathrm{kg}^{-1}\right)$ showed no apoptotic vessels or tumour necrosis (Figure 1E; Table 1). No staining was observed with liver sections from either normal or tumour-bearing mice, before or $3 \mathrm{~h}$ after DMXAA $\left(25 \mathrm{mg} \mathrm{kg}^{-1}\right)$ (Figure 1F). Strong staining for apoptosis was observed in the central vessel in the white pulp regions of spleens from all tumour-bearing mice $3 \mathrm{~h}$ after DMXAA (Figure 1G), and was not present without treatment. Apoptosis in the splenic vasculature was tumour-dependent, since apoptotic cells were not observed in spleens from normal mice following DMXAA administration (Figure $1 \mathrm{H}$ ). 
Table I Quantitation of apoptotic vessels following DMXAA treatment

\begin{tabular}{lccccc}
\hline Tumour/treatment & Dose & Time & $\mathbf{n}^{\mathbf{a}}$ & $\begin{array}{c}\text { Apoptotic vessels } \\
\text { (percentage) }\end{array}$ & $\begin{array}{c}\text { Apoptotic vessels } \\
\text { per fieldc }\end{array}$ \\
\hline Colon 38 & & & & & \\
Untreated & & 6 & $3.7 \pm 1.5$ & $0.33 \pm 0.21$ \\
DMXAA & $25 \mathrm{mg} \mathrm{kg}^{-1}$ & $30 \mathrm{~min}$ & 13 & $32 \pm 2(P<0.00 \mathrm{I})$ & $1.8 \pm 0.3(P<0.0 \mathrm{I})$ \\
DMXAA & $25 \mathrm{mg} \mathrm{kg}^{-1}$ & $1 \mathrm{~h}$ & 14 & $30 \pm 4(P<0.00 \mathrm{I})$ & $1.5 \pm 0.2(P<0.05)$ \\
DMXAA & $25 \mathrm{mg} \mathrm{kg}^{-1}$ & $3 \mathrm{~h}$ & 8 & $68 \pm 8(P<0.00 \mathrm{I})$ & $3.1 \pm 0.8(P<0.05)$ \\
DMXAA & $15 \mathrm{mg} \mathrm{kg}^{-1}$ & $3 \mathrm{~h}$ & 10 & $27 \pm 3(P<0.00 \mathrm{I})$ & $1.5 \pm 0.2(P<0.0 \mathrm{I})$ \\
DMXAA & $10 \mathrm{mg} \mathrm{kg}^{-1}$ & $3 \mathrm{~h}$ & 7 & $11 \pm 4$ & $0.57 \pm 0.20$ \\
DMXAA & $5 \mathrm{mg} \mathrm{kg}^{-1}$ & $3 \mathrm{~h}$ & 7 & $10 \pm 5$ & $0.57 \pm 0.20$ \\
8-MeXAA & $220 \mathrm{mg} \mathrm{kg}^{-1}$ & $3 \mathrm{~h}$ & 2 & $1.8 \pm 1.2$ & $0.33 \pm 0.20$ \\
Human breast & & & & & \\
Pre-treatment & & & 4 & N.D. & $0.0 \pm 0.0$ \\
DMXAA & $3.1 \mathrm{mg} \mathrm{m}^{-2}$ & $3 \mathrm{~h}$ & 4 & N.D. & $3.5 \pm 0.9(P<0.00 \mathrm{I})$ \\
DMXAA & $3.1 \mathrm{mg} \mathrm{m}^{-2}$ & $24 \mathrm{~h}$ & 7 & N.D. & $9.1 \pm 0.5(P<0.00 \mathrm{I})$ \\
\hline
\end{tabular}

${ }^{a}$ Number of fields scored from different sections taken from 2-4 Colon 38 tumour-bearing mice or from the human tumour sections. ${ }^{b}$ Percentage of Colon 38 tumour vessels positive for the TUNEL assay. The total number of vessels was determined by staining with anti-CD-3I antibody. Mean+s.e.m. Significance of difference from control is shown where $P<0.05$ (Student's $t$-test). 'Number of TUNEL-stained vessels per $1 \mathrm{~mm}^{2}$ field, counted at $20 \times$ magnification. Mean \pm s.e.m. from Colon 38 tumour sections or from human breast carcinoma biopsies from the same patient before and after treatment with DMXAA. Significance of difference from control is shown where $P<0.05$ (Student's t-test). ${ }^{d}$ Not determined, since human tumour sections were not double-stained with anti-CD31 antibodies to quantitate the total number of vessels.
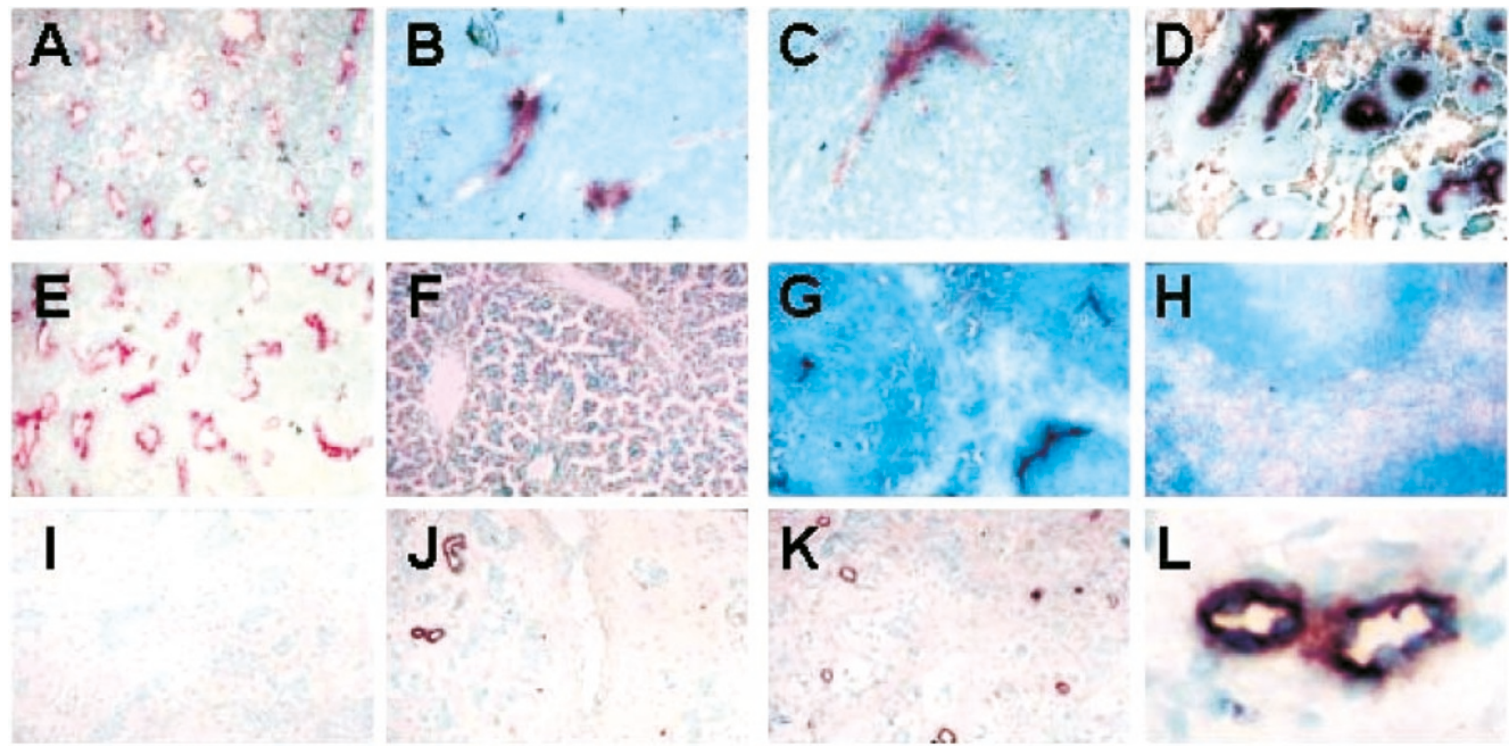

Figure I Induction of endothelial cell apoptosis by DMXAA. (A-E) Representative cryosections of Colon 38 tumours (I00 $\times$ magnification) were immunostained for apoptosis using TUNEL (black) and endothelial cells with antibodies to CD-3I (red): (A) untreated, (B) 30 min after DMXAA $\left(25 \mathrm{mg} \mathrm{kg}^{-1}\right)$, (C) I h after DMXAA, (D) $3 \mathrm{~h}$ after DMXAA, (E) $3 \mathrm{~h}$ after 8-MeXAA $\left(220 \mathrm{mg} \mathrm{kg}^{-1}\right)$. (F-H) Representative cryosections (I $00 \times$ magnification) immunostained for apoptosis using TUNEL (black): (F) liver tissue from Colon 38 tumour-bearing mice $3 \mathrm{~h}$ after DMXAA (25 mg kg-1), (G) spleen tissue from Colon 38-bearing mice $3 \mathrm{~h}$ after DMXAA $\left(25 \mathrm{mg} \mathrm{kg}^{-1}\right)$, and $(\mathbf{H})$ spleen tissue from normal mice $3 \mathrm{~h}$ after DMXAA (25 mg kg $\left.{ }^{-1}\right)$. (IL) Representative cryosections ( $100 \times$ magnification) from a human breast carcinoma immunostained for apoptosis using TUNEL (black): (I) before treatment, (J) $3 \mathrm{~h}$ after DMXAA infusion (3.1 $\mathrm{mg} \mathrm{m}^{-2}$ ), (K) $24 \mathrm{~h}$ after DMXAA. (L) Section at higher magnification (500 $\times$ ) of two vessels $3 \mathrm{~h}$ after DMXAA infusion.

\section{Endothelial cell apoptosis in human tumours following DMXAA}

Tumour biopsies from one patient with breast adenocarcinoma prior to DMXAA infusion $\left(3.1 \mathrm{mg} \mathrm{m}^{-2}\right)$ did not stain with the TUNEL assay (Figure 1I). However apoptotic staining in vessels was seen in the biopsy taken $3 \mathrm{~h}$ post-infusion (Figure 1J) and the number of apoptotic vessels increased three-fold in the biopsy taken after $24 \mathrm{~h}$ (Figure 1K; Table 1). In contrast with the murine $3 \mathrm{~h}$ samples, haemorrhagic necrosis was not observed. In another two patients administered DMXAA at 3.7 and $4.9 \mathrm{mg} \mathrm{m}^{-2}$ no staining for apoptosis was seen in samples taken prior to drug infusion nor in breast carcinoma samples taken at 3 and $24 \mathrm{~h}$ or ovarian carcinoma samples taken at $4.5 \mathrm{~h}$.

\section{DMXAA induces HECPP endothelial cell apoptosis in culture}

We used the murine endothelial HECPP cell line (Bizouarne et $a l, 1993)$ to determine whether DMXAA could induce apoptosis 
in vitro in the absence of TNF induction. As seen from Northern blot analyses, DMXAA does not induce mRNA for TNF or interferons in the HECPP cells (Figure 2A). Of the cytokine genes that are up-regulated in mice following DMXAA treatment (Figure 2B), only mRNA for IP-10 was up-regulated following $2 \mathrm{~h}$ incubation with DMXAA at $400 \mu \mathrm{g} \mathrm{ml}^{-1}$ in the HECPP cells (Figure 2A). HECPP cells treated with DMXAA were processed using TUNEL assays and the percentages of apoptotic cells were determined by counting at least 500 cells. Following exposure to DMXAA at a concentration $\left(400 \mu \mathrm{g} \mathrm{ml}^{-1}\right)$ that is achievable in vivo after administration of an effective antitumour dose (McKeage et al, 1991), apoptotic cells were seen after $6 \mathrm{~h}$ incubation, and the numbers increased with prolonged exposure (Figure $3 \mathrm{~A})$. Apoptotic cell numbers at $24 \mathrm{~h}$ increased linearly with increasing dose of DMXAA above $100 \mu \mathrm{g} \mathrm{ml}^{-1}$. The DMXAA concentration that induced $50 \%$ apoptosis after incubation for $24 \mathrm{~h}$ was $500 \mu \mathrm{g} \mathrm{ml}^{-1}$ (Figure $3 \mathrm{~B}$ ).

\section{DISCUSSION}

These results are the first to demonstrate the selective induction of endothelial cell apoptosis in both a murine tumour (Figure $1 \mathrm{~B}-\mathrm{D}$ ) and a human tumour (Figure $1 \mathrm{~J}-\mathrm{L}$ ) following treatment with DMXAA. Loss of tumour vascular endothelial cells by apoptosis would be expected to increase the permeability of the vascular endothelium, providing a potential mechanism for reduction in tumour blood flow (Baguley, 2001) as demonstrated in both murine models (Zwi et al, 1994a,b; Lash et al, 1998) and in clinical studies (Rustin et al, 1998). The results also provide a possible mechanism for the DMXAA-induced extravasation of erythrocytes in murine tumours (Zwi et al, 1994b). Although a number of studies have implicated TNF in the antitumour response of DMXAA (Browne et al, 1998; Cao et al, 1999), three observations in this study support a TNF-independent action of DMXAA on the vascular endothelium. Firstly, apoptosis of endothelial cells was observed in Colon 38 tumour sections with- in $30 \mathrm{~min}$ after administration, well before the time at which TNF is detectable in plasma or tumour tissue (Joseph et al, 1999). Secondly, in the patient where apoptosis was induced in tumour vessels following treatment with DMXAA, no TNF induction was detectable in tumour tissue or plasma (Jameson et al, 2000). Thirdly, apoptosis was induced with increasing concentrations of DMXAA in HECPP cells in culture (Figure 3 ) when the cells did not produce TNF (Figure 2A). Of all the cytokine genes that are known to be induced in vivo by DMXAA in murine tissues (Cao et al, 2001), only mRNA for IP-10 was up-regulated in cultures of HECPP cells (Figure 2A). IP-10 is known for its chemotactic (Luster et al, 1985; Taub et al, 1993) and anti-angiogenic activities (Angiolillo et al, 1995) but has no reported apoptotic activity. Our results here suggest that DMXAA may have a direct apoptotic effect on endothelial cells.

The induction of endothelial apoptosis in tumour tissue by DMXAA is not completely tumour-selective. While no apoptosis was observed in sections from liver of normal or tumour-bearing mice (Figure 1E), apoptotic cells were detected in the vasculature of spleens from tumour-bearing animals (Figure 1G). Since such cells were not observed in spleens of normal mice (Figure $1 \mathrm{H}$ ), the tumour appears to sensitise endothelial cells in spleen, but not liver, to apoptosis induction by DMXAA. A possible reason for this is that factors released from tumours activate splenocytes, which then react to DMXAA by releasing TNF, thus inducing endothelial cell apoptosis and reducing splenic blood flow. The results are consistent with the observation that splenic perfusion was transiently and selectively lowered in tumour-bearing mice following treatment with FAA (flavone-8-acetic acid), a drug related structurally to DMXAA (Honess and Bleehen, 1991). Previous work from our laboratory has indicated the presence of tumour-secreted factors leading to priming of tumoricidal macrophages and their responsiveness to activation by DMXAA (Ching et al, 1993). The procoagulant activity of human endothelial cells in culture is strongly up-regulated by condi-
A

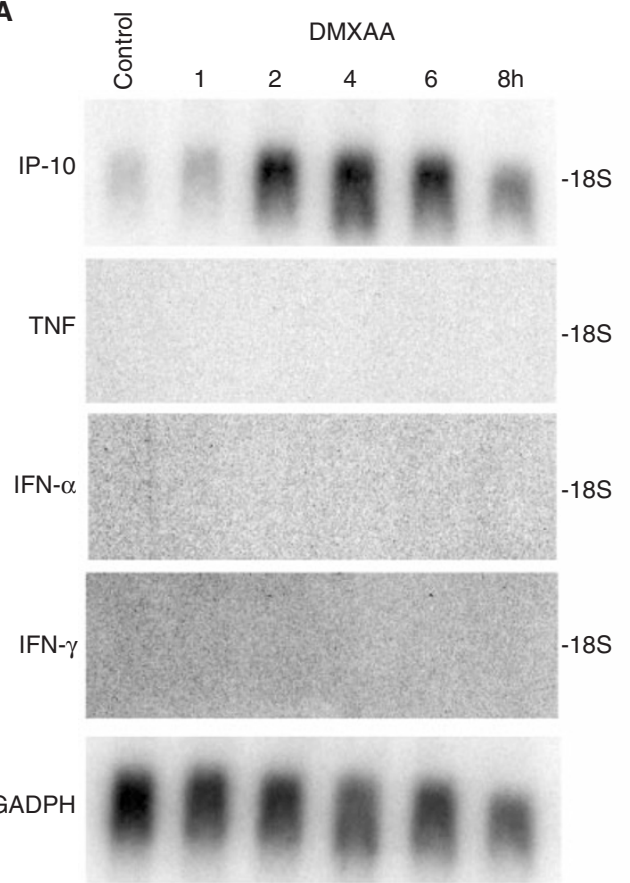

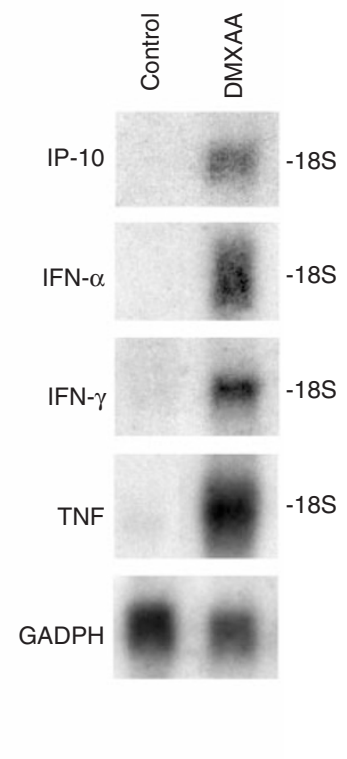

Figure 2 Northern blots for mRNA expression. (A) mRNA for IP-I0, TNF, IFN- $\alpha$, IFN- $\gamma$ in HECPP cells detected $2 \mathrm{~h}$ following in vitro treatment with DMXAA (400 $\left.\mu \mathrm{g} \mathrm{ml}^{-1}\right)$. Loading of each lane shown by GADPH mRNA levels. Untreated controls (lane C). (B) mRNA for IP- I0, TNF, IFN- $\alpha$, IFN- $\gamma$ in murine splenocytes detected $2 \mathrm{~h}$ following in vivo treatment with DMXAA $\left(25 \mathrm{mg} \mathrm{kg}^{-1}\right)$. 
A

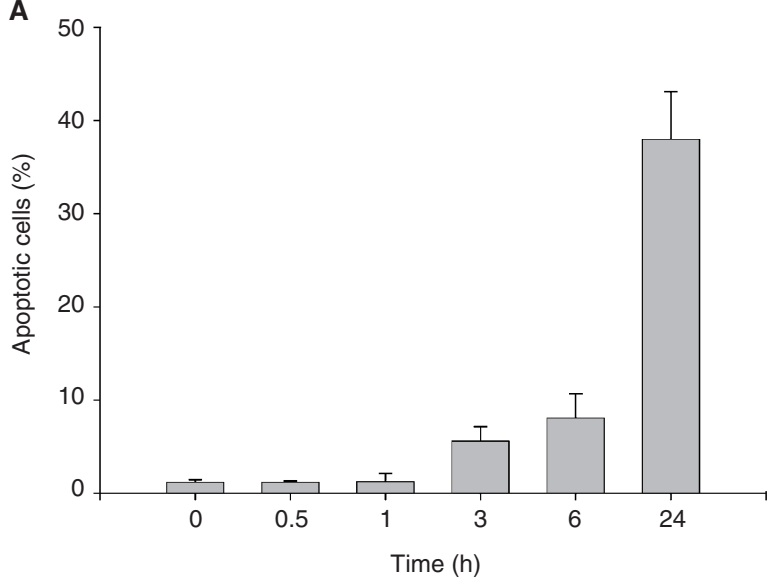

B

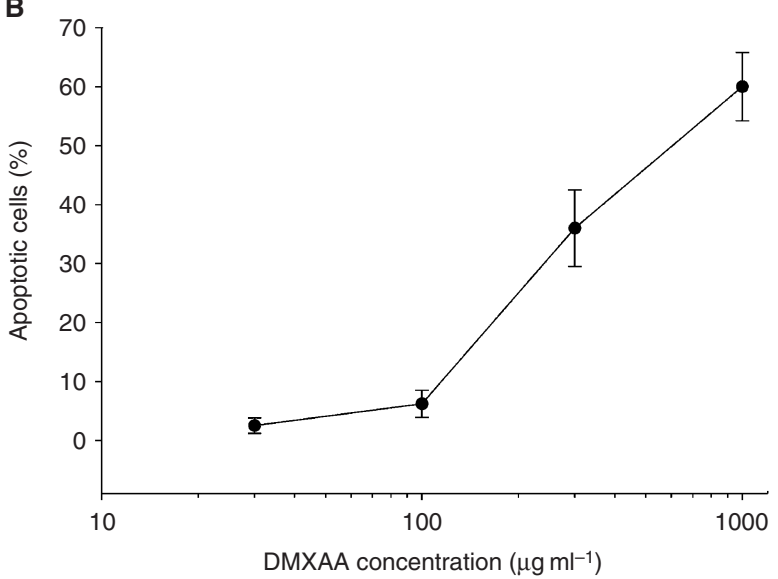

Figure 3 Induction of apoptosis by DMXAA in cultured HECPP endothelial cells. (A) Percentage of HECPP cells stained using TUNEL assay for apoptosis after various incubation times with DMXAA $\left(400 \mu \mathrm{g} \mathrm{ml}{ }^{-1}\right)$. (B) Percentage TUNEL-staining HECPP cells $24 \mathrm{~h}$ after exposure to different DMXAA concentrations. Mean \pm s.e.m. of at least three determinations, obtained by counting 500 cells.

tioned growth medium from a cultured human breast adenocarcinoma cell line. The tumour conditioned medium had a greater effect on endothelial cells than did hypoxia, reduced oxygen tension, TNF, FAA or DMXAA (Watts et al, 1996), providing another clear example of the priming effect of tumour secreted factors.

The 'priming' effect may provide an explanation of the remarkably rapid onset $(30 \mathrm{~min}$ ) of apoptosis of vascular endothelial cells in the Colon 38 tumour. It is not known whether vascular endothelial apoptosis could occur as rapidly in human tumours, since the earliest time point following DMXAA that we were able to examine was $3 \mathrm{~h}$. However, apoptosis occurred more rapidly following DMXAA administration in vivo than in HECPP cells in culture.

Clinical trials of DMXAA have indicated a low response rate to DMXAA (Jameson et al, 2000). However, good evidence has been provided for induced vascular effects, such as reduced tumour blood flow (Rustin et al, 1998), serotonin release (Jameson et al, 2000) and the endothelial apoptosis reported in this study. The clinical trial results differ from those of murine studies in that although TNF synthesis was detected in one human tumour sample (Jameson et al, 2000) the level was low and TNF was not detected in the sample in which endothelial cell apoptosis was observed. Widespread haemorrhagic necrosis is a prominent effect of DMXAA treatment in murine tumours (Baguley et al, 1989; Zwi et al, 1994b; Cao et al, 1999) but has not so far been observed in clinical trials. In the Colon 38 tumour, in situ TNF synthesis (Joseph et al, 1999) is probably responsible for sustaining the vascular effect of DMXAA and inducing haemorrhagic necrosis. Combination of DMXAA with agents that improve intratumoural TNF synthesis might constitute a rational approach in further clinical trials of DMXAA. In cultured human peripheral blood leucocytes, a second signal, such as that provided by trace amounts of endotoxin or interleukin-1, is required in order for DMXAA to induce TNF production (Philpott et al, 2001). Clinical studies employing DMXAA in combination with other agents that provide a second signal within tumour tissue may provide a pathway towards improved anticancer therapy.

\section{ACKNOWLEDGEMENTS}

This work was supported by the Auckland Division of the Cancer Society of New Zealand. The research was conducted during the tenure (by Z Cao) of a Postgraduate Scholarship of the Health Research Council of New Zealand.

\section{REFERENCES}

Angiolillo AL, Sgadari C, Taub DD, Liao F, Farber JM, Maheshwari S, Kleinman HK, Reaman GH, Tosato G (1995) Human interferon-inducible protein 10 is a potent inhibitor of angiogenesis in vivo. J Exp Med 182: $155-162$

Baguley BC (2001) Small-molecule cytokine inducers causing tumor necrosis. Curr Opin Investig Drugs 2: 967-975

Baguley BC, Calveley SB, Crowe KK, Fray LM, O'Rourke SA, Smith GP (1989) Comparison of the effects of flavone acetic acid, fostriecin, homoharringtonine and tumour necrosis factor alpha on Colon 38 tumors in mice. Eur J Cancer Clin Oncol 25: 263-269

Bizouarne N, Mitterrand M, Monsigny M, Kieda C (1993) Characterization of membrane sugar-specific receptors in cultured high endothelial cells from mouse peripheral lymph nodes. Biol Cell 79: 27-35

Browne WL, Wilson WR, Baguley BC, Ching L-M (1998) Suppression of serum tumour necrosis factor-alpha by thalidomide does not lead to reversal of tumour vascular collapse and anti-tumour activity of 5,6dimethylxanthenone-4-acetic acid. Anticancer Res 18: 4409-4414

Cao Z, Joseph WR, Browne WL, Mountjoy KG, Palmer BD, Baguley BC, Ching LM (1999) Thalidomide increases both intra-tumoural tumour necrosis factor-alpha production and anti-tumour activity in response to 5,6-dimethylxanthenone-4-acetic acid. Br J Cancer 80: 716-723

Cao Z, Baguley BC, Ching L-M (2001) Interferon-inducible protein 10 induction and inhibition of angiogenesis in vivo by the antitumor agent 5,6dimethylxanthenone-4-acetic acid (DMXAA). Cancer Res 61: 1517-1521

Ching LM, Joseph WR, Baguley BC (1993) Effect of tumour growth on the macrophage response to the antitumour agent 5,6-dimethylxanthenone4-acetic acid. Anticancer Res 13: 2069-2075

Ching LM, Joseph WR, Crosier KE, Baguley BC (1994) Induction of tumor necrosis factor-alpha messenger RNA in human and murine cells by the flavone acetic acid analogue 5,6-dimethylxanthenone-4-acetic acid (NSC 640488). Cancer Res 54: 870-872

Ching LM, Goldsmith D, Joseph WR, Korner H, Sedgwick JD, Baguley BC (1999) Induction of intratumoral tumor necrosis factor (TNF) synthesis and hemorrhagic necrosis by 5,6-dimethylxanthenone-4-acetic acid (DMXAA) in TNF knockout mice. Cancer Res 59: 3304-3307

Honess DJ, Bleehen NM (1991) Effects of two tumour blood flow modifiers, hydralazine and flavone acetic acid, on KHT tumours and normal tissues in mice. Int J Radiat Biol 60: 249-253

Jameson MB, Thompson PI, Baguley BC, Evans BD, Harvey VJ, Porter DJ, McCrystal MR, Kestell P (2000) Phase I pharmacokinetic and pharmacodynamic study of 5,6-dimethylxanthenone-4-acetic acid (DMXAA), a novel antivascular agent. Proc Am Soc Clin Oncol 19: 182a 
Joseph WR, Cao Z, Mountjoy KG, Marshall ES, Baguley BC, Ching L-M (1999) Stimulation of tumors to synthesize tumor necrosis factor-alpha in situ using 5,6-dimethylxanthenone-4-acetic acid: a novel approach to cancer therapy. Cancer Res 59: 633-638

Lash CJ, Li AE, Rutland M, Baguley BC, Zwi LJ, Wilson WR (1998) Enhancement of the anti-tumour effects of the antivascular agent 5,6-dimethylxanthenone-4-acetic acid (DMXAA) by combination with 5-hydroxytryptamine and bioreductive drugs. $\mathrm{Br} \mathrm{J}$ Cancer 78: 439445

Luster AD, Unkeless JC, Ravetch JV (1985) Gamma-interferon transcriptionally regulates an early-response gene containing homology to platelet proteins. Nature 315: $672-676$

McKeage MJ, Kestell P, Denny WA, Baguley BC (1991) Plasma pharmacokinetics of the antitumour agents 5,6-dimethylxanthenone-4-acetic acid, xanthenone-4-acetic acid and flavone-8-acetic acid in mice. Cancer Chemother Pharmacol 28: 409-413

Philpott M, Baguley BC, Ching L-M (1995) Induction of tumour necrosis factor-alpha by single and repeated doses of the antitumour agent 5,6dimethylxanthenone-4-acetic acid. Cancer Chemother Pharmacol 36: $143-148$

Philpott M, Ching LM, Baguley BC (2001) The antitumour agent 5,6dimethylxanthenone-4-acetic acid acts in vitro on human mononuclear cells as a co-stimulator to other inducers of tumour necrosis factor. Eur J Cancer 37: 1930 - 1937

Rewcastle GW, Atwell GJ, Zhuang L, Baguley BC, Denny WA (1991) Potential antitumor agents. 61. Structure-activity relationships for in vivo colon 38 activity among disubstituted 9-oxo-9H-xanthene-4-acetic acids. J Med Chem 34: 217-222
Rustin G, Galbraith S, Taylor N, Stratford M, Bradley C, Thompson P, Jameson M, Baguley B (1998) Impact on tumour perfusion measured by dynamic magnetic resonance imaging (MRI), in the phase 1 trial of 5,6dimethylxanthenone-4-acetic acid (DMXAA). Ann Oncol 9: 126

Taub DD, Lloyd AR, Conlon K, Wang JM, Ortaldo JR, Harada A, Matsushima K, Kelvin DJ, Oppenheim JJ (1993) Recombinant human interferon-inducible protein 10 is a chemoattractant for human monocytes and T lymphocytes and promotes $\mathrm{T}$ cell adhesion to endothelial cells. J Exp Med 177: $1809-1814$

Vecchi A, Garlanda C, Lampugnani MG, Resnati M, Matteucci C, Stoppacciaro A, Schnurch H, Risau W, Ruco L, Mantovani A, Dejana E (1994) Monoclonal antibodies specific for endothelial cells of mouse blood vessels. Their application in the identification of adult and embryonic endothelium. Eur J Cell Biol 63: 247-254

Watts ME, Arnold S, Chaplin DJ (1996) Changes in coagulation and permeability properties of human endothelial cells in vitro induced by TNF-alpha or 5,6-MeXAA. Br J Cancer 74: S164-S167

Workman P, Twentyman P, Balkwill F, Balmain A, Chaplin D, Double J, Embleton J, Newell D, Raymond R, Stables J, Stephens T, Wallace J (1998) United Kingdom Co-ordinating Committee on Cancer Research (UKCCCR) Guidelines for the Welfare of Animals in Experimental Neoplasia (Second Edition). Br J Cancer 77: 1-10

Zwi LJ, Baguley BC, Gavin JB, Wilson WR (1994a) Correlation between immune and vascular activities of xanthenone acetic acid antitumor agents. Oncol Res 6: 79-85

Zwi LJ, Baguley BC, Gavin JB, Wilson WR (1994b) The morphological effects of the anti-tumour agents flavone acetic acid and 5,6-dimethylxanthenone acetic acid on the colon 38 mouse tumour. Pathology 26: 161-169 